\title{
Protection of Limestone Coated with Different Polymeric Materials
}

\author{
Mohammed Y. Abdellah, 1,4,* A. F. Gelany ${ }^{2}$, Ahmed F. Mohamed ${ }^{3,4}$, Ahmed Bakr Khoshaim ${ }^{4}$ \\ ${ }^{1}$ Mechanical Engineering Department, Faculty of Engineering, South Valley University, Qena, Egypt \\ ${ }^{2}$ Faculty of Science, South Valley University, Qena, Egypt \\ ${ }^{3}$ Mechanical Engineering Department, Faculty of Engineering, Sohag University, Sohag, Egypt \\ ${ }^{4}$ Mechanical Engineering Department, Collage of Engineering and Islamic Architecture, \\ Umm Al-Qura University Makkah, KSA \\ *Corresponding author: mohammed_yahya42@yahoo.com
}

\begin{abstract}
The uniaxial compressive strength is an important parameter in selecting and design of rock and brittles structure. Protection of ancient monuments or historic structure has a great intense in material science point of view. Limestone is commonly rock material which has a great sense in historical buildings and temples. The strength of this material may be influenced by natural weathering like moisture, rains and varying temperature. Samples of ancient limestone rock are coated with Paraloid B44, Paraloid B72, ethyl silicate and Wacker OH100. The results concluded that both Wacker OH100 and Paraloid B44 coating material have more efficient and give considerable protection when the sample is immersed in salinity water for a week. The compressive strength of limestone decreases due to water action. Water absorption, porosity, and rock density are enhanced with the coating process.
\end{abstract}

Keywords: limestone, compressive strength of rock, coating rocks, temples

Cite This Article: Mohammed Y. Abdellah, A. F. Gelany, Ahmed F. Mohamed, and Ahmed Bakr Khoshaim, "Protection of Limestone Coated with Different Polymeric Materials." American Journal of Mechanical Engineering, vol. 5, no. 2 (2017): 51-57. doi: 10.12691/ajme-5-2-3.

\section{Introduction}

The rock of limestone mainly composed of calcium carbonate $\left(\mathrm{CaCO}_{3}\right)$. Weathering conditions like atmospheric pollution, salty groundwater absorption are the main reasons for the deterioration of historical buildings [1]. Many works were on the deterioration of marble and limestone [2-8]. The improvement, strengthening, and protection of ancient buildings are attractive and having great intense in a lot of societies. Deeply understanding the behaviors of ancient material would give good and satisfied results for improvement and protection process [9]. A lot of developments in the experimental and numerical investigations of ancient buildings rehabilitation are occurred [10].

Cheshomi and Ahmadi Sheshde [11] determined the uniaxial compressive strength of microcrystalline limestone using single particles load test.

Ramli Nazir et al [12] investigated the unconfined compressive strength (UCS) of the rock comparing it with Schmidt hammer test. Their results are summarized that Miller`s correlation reliability was high enough and it closely agreed with the new proposed correlation.

Sadat-Shojai and Ershad-Langroudi [13] reviewed the different protection methods of historical buildings using a polymeric coating. There review introduced some polymeric material which is used in protection fields such as acrylics, alkoxysilanes, fluorinated polymers, and hybrid organic-inorganic coatings. In recent years, a lot of synthetic polymers have a distinguished application in the treatment of construction materials of historical monuments for consolidation and conservation of such structures [14].

Tuğrul [15] studied the effect of weathering on the compressive strength of 4 types of rock (Sandstone, Limestone, Basalt, and Granodiorite). The results gave an observable change in porosity and microspores. Compressive strength decreased with porosity increased. serous microfracture and pore connectivity were seen.

Karaca et al. [16] investigated the influence of Freezethaw cycles, aqueous saline solution. They concluded that surface finished and cement filling have a great important for the deterioration of limestones. Therefore, they recommended that for outdoors applications fine finished surfaced with cement-filled would be distinguished.

Abdellah et al. [17] investigated the protection of historic sandstone using chemical polymeric solvent. It is concluded that ethyl silicate coating material is more efficient and gives considerable protection when the sample is immersed in water for a week. The compressive strength of sandstone decreases due to water action.

Tsakalof et al [18] protected some historic stones (marble, travertine, sandstone and black bricks) using the polymeric material. They summarized that the efficiency of the coating varies from stone substrate to another. In another study by Zielecka \& Bujnowska [19] silicon polymer organic matrix was used as a coating agent for porous stone. They used Fluoropolymers, polyolefins, and acrylic resins. Their study concluded that selecting types 
of the polymer was a critical agent for surface properties of these coating.

Protection of monument by using polymeric coatings was of great intense in a lot of works [20,21,22,23,24,25].

\section{Goal of the Present Study}

The main goals of the present study are as follows;

1. To investigate the efficiency of the different chemical polymeric coatings to protect historic limestone deteriorates.

2. To get the best suitable polymer to protect the rock from weathering effect.

The methodology of the present paper is as follows; first section summarizes the used materials specifications. The second one studies the coating and manufacturing technique. Finally, the obtained results are outlined and relation are explained.

\section{Materials and Characterization}

Historical limestone taken from Qurna mountain of Thebes near HASEBSHOUT temple in upper Egypt is used. The x-ray diffraction of this material is analyzed for four specimens as shown in (Figure 1). Components taken from XRD of each specimen are listed in Table 1. The chemical coating materials which are Paraloid 44 (B44), Paraloid 72 (B72), Ethyl silicate and Wacker (OH100), are listed in Table 2. EDX analysis revealed a prominent $\mathrm{Cl}$ peak. The level of the latter was high relative to other detectable elements such as $\mathrm{Na}$ and $\mathrm{K}$, indicating salting as the cause of degradation. with no apparent $\mathrm{Cu}$ staining, as confirmed by EDX. The $\mathrm{Ca} / \mathrm{P}$ ratios for the limestone samples were calculated using the atomic \% of $\mathrm{Ca}$ and $\mathrm{P}$, which was obtained from EDX chemical analysis. The detailed analyses reveal that the chemical composition of the sample is not homogeneous. There are variations on the inside and outside of the sample. The results of the analysis performed on $\mathrm{P} 1$ confirms that it is unaltered limestone since only $\mathrm{Ca}$ and $\mathrm{O}$ are present. EDX (Figure 2) listed in Table 3.

Table 1. XRD analysis results for Thebes limestone near HASEBSHOUT temple

\begin{tabular}{ccc}
\hline Sample & Major minerals & Minor minerals \\
\hline \multirow{2}{*}{1} & $\begin{array}{c}\text { Calcite } \\
\text { Dolomite } \\
\text { Gypsum }\end{array}$ & $\begin{array}{c}\text { Montimorillionite } \\
\text { Haematite }\end{array}$ \\
\hline 2 & Calcite & Montimorillionite \\
& Analomite \\
Gypsum & Aalcite & Montimorillionite \\
\hline 3 & Dolomite & Montimorillionite \\
Gypsum
\end{tabular}

Table 2. Chemical Composition of coated materials

\begin{tabular}{cc}
\hline Materials & Chemical composition \\
\hline Paraloid B44 & MMA copolymer \\
\hline Paraloid B72 & Copolymere ethylmetacry-metylacrylate \\
\hline ethyl silicate & $\mathrm{Si}_{\left(\mathrm{OC}_{2} \mathrm{H}_{5}\right)_{4}}$ \\
\hline Wacker OH100 & Cyclohexylmethyl-dimethoxysilane \\
\hline
\end{tabular}

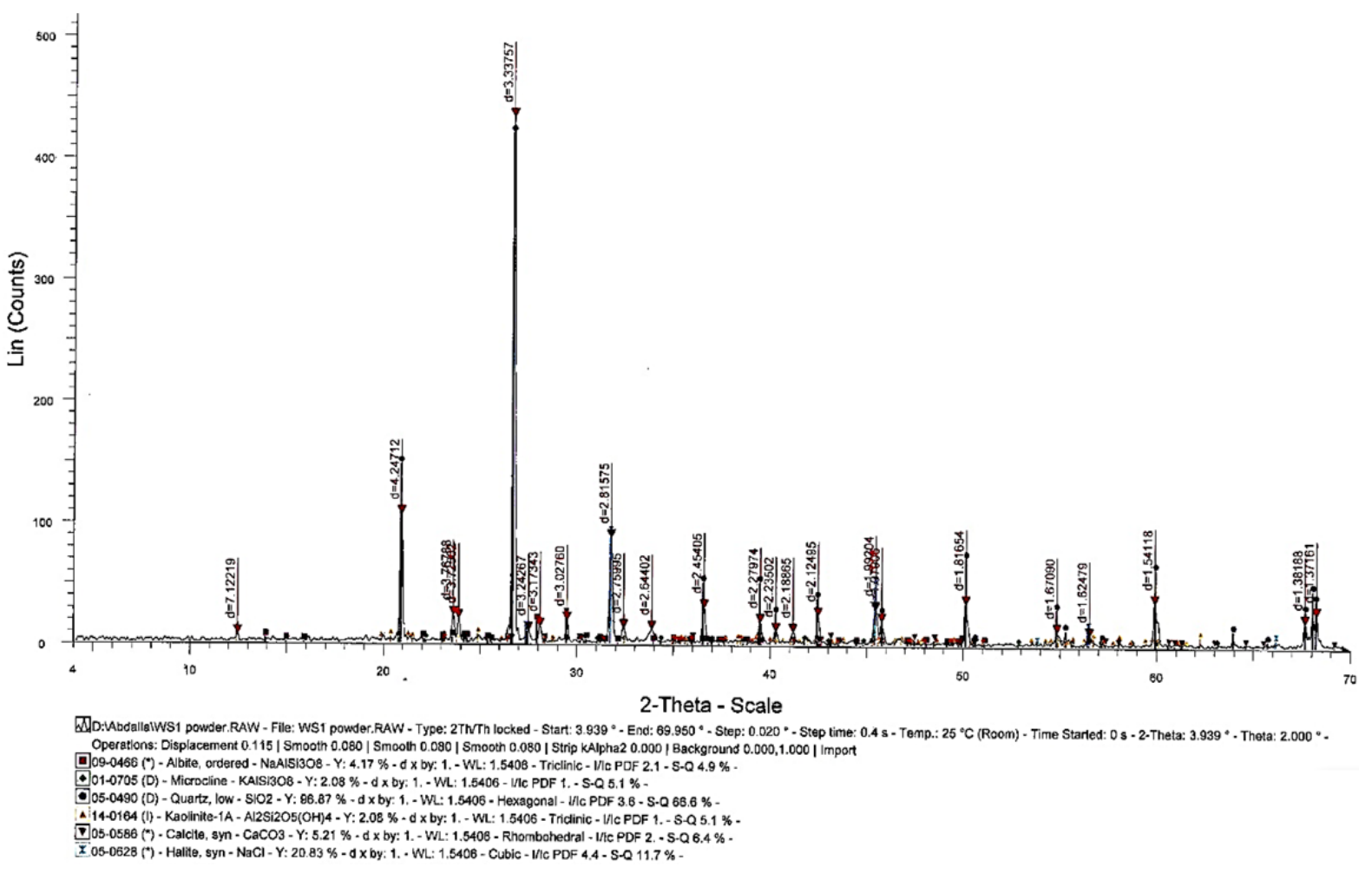

Figure 1. XRD analysis of historical limestone one sample of Thebes mountain

Table 3. EDX analysis results for Thebes limestone near HASEBSHOUT temple (ms\%)

\begin{tabular}{|c|c|c|c|c|c|c|c|c|c|c|}
\hline Element & $\mathrm{Al}$ & $\mathrm{Si}$ & $S$ & $\mathrm{Cl}$ & $\mathrm{Ca}$ & $\mathrm{Fe}$ & $\mathrm{Sr}$ & $\mathrm{Mg}$ & $\mathrm{K}$ & $\mathrm{Ti}$ \\
\hline Avg. & 1.50215 & 9.589783 & 1.437 & 1.20998 & 246.5924 & 9.0367 & 0.5112 & 1.7142 & 0.789 & 0.8555 \\
\hline
\end{tabular}




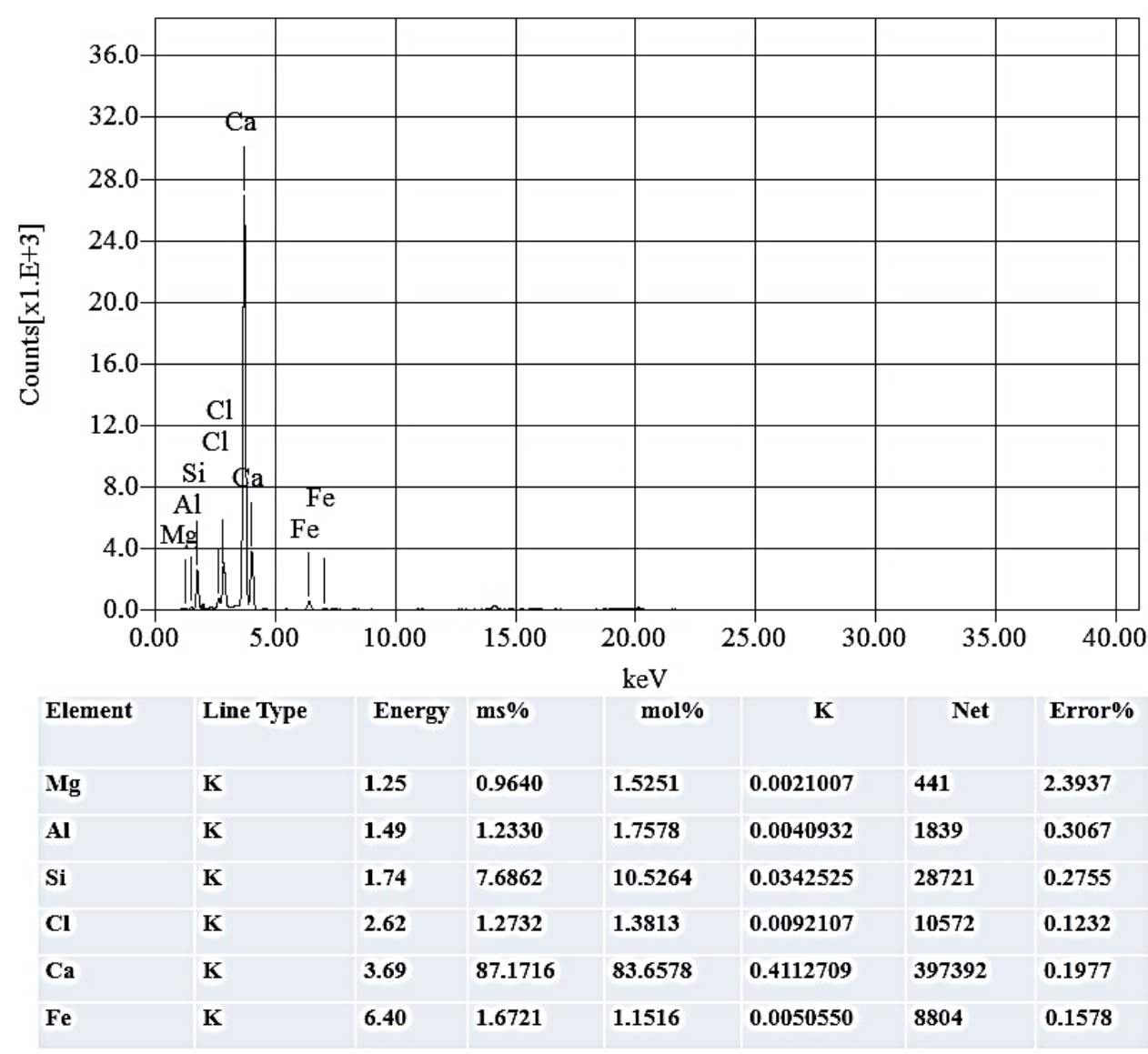

Figure 2. EDX analysis of historical limestone of Thebes mountain

\section{Experimental Work}

The as received limestone of $(30 \mathrm{~mm} \times 30 \mathrm{~mm} \times 30 \mathrm{~mm})$ is tested in compassion using computerized universal testing machine (model WDW-100) at $1 \mathrm{~mm} /$ min crosshead speed. Four groups of tested specimens are coated by chemical material Paraloid 44 (B44), Paraloid 72 (B72), ethyl silicate and Wacker OH100. The coating process is performed by immersion of limestone specimens into the coating chemicals for $72 \mathrm{hr}$. for each. The limestone coated with the various solvent and that without coating are immersed in salty groundwater path for 15 days continuously. The density of the as received and chemically treated rocks is measured. Moreover, the porosity and water absorption are calculated according ASTM- D1037-06a [26] using Eq. 1. The compression test is carried out according to ASTM D2938-95 [27].

$$
W A(\%)=\frac{W_{f}-W_{i}}{W_{i}} \times 100
$$

where, $W_{f}$ is the final weight after soaking for 72 hours and $W_{i}$ is the initial weight.

\section{Results and Discussion}

\subsection{Microstructure Examination}

Figure 3 shows SEM photographic examination. It is clear that Paraloid B44 has a thick layer with voids and pores appeared. Partially distribution in the surface structure of limestone (see Figure 3 a). In (Figure 3 b) thick film and dense distribution of Paraloid B72 are closing of the stone. For Wacker $(\mathrm{OH} 100)$ good penetration in homogeneous form with the internal structure of limestone as in Figure 3-C, while, ethyl silicate (ESL) has many voids and pore which weaken the coating efficiency (see Figure 3-d).

\subsection{Compressive Strength}

Figure 4 shows a compressive stress-strain diagram of treatable surfaced limestone. It clearly appears that limestone coated with Paraloid (B44) and Wacker (OH 100) has good adhesive and strength than other coating polymers (clearly shown in Figure 6). This is due to highly uniformly distribution of (B44) and (OH100) see Figure 3. The flow curves of the most tested specimens are not smooth; this can be attributed to macrocracks emanating during the action of compression load. The enhancement of strength for all specimens with respect to the untreatable limestone (as-receive) are listed in Table 4 and Table 5 and they are illustrated clearly in Figure 7 which gives a percent of increase of nominal strength ( $S_{n}=\frac{\sigma_{\text {treatable }}}{\sigma_{\text {un-treatable }}}$ ) with each coating agent. Figure 5 shows compressive stress-strain diagram after the immersion of the treatable and untreatable limestone in salinity water path. The presence of Gypsum $\left(\mathrm{CaSO}_{4} \cdot 2 \mathrm{H}_{2} \mathrm{O}\right)$ was created through the reactions between limestone and sulfate sources, according to the following reaction:

$\mathrm{Ca} \mathrm{CO}_{3}+\mathrm{Na}_{2} \mathrm{SO}_{4}+2 \mathrm{H}_{2} \mathrm{O} \rightarrow$ Ca SO $4.2 \mathrm{H}_{2} \mathrm{O}+\mathrm{Na}_{2} \mathrm{CO}_{3}$. 


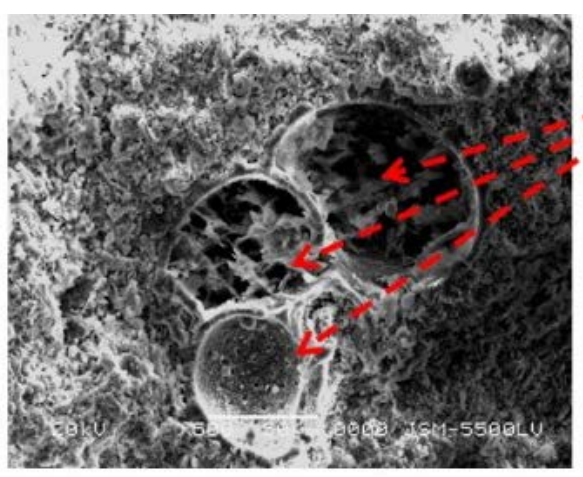

a) Limestone Coated with B44

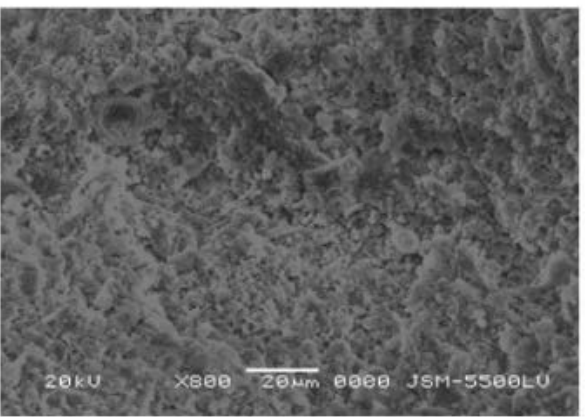

C) Limestone coated with WAC

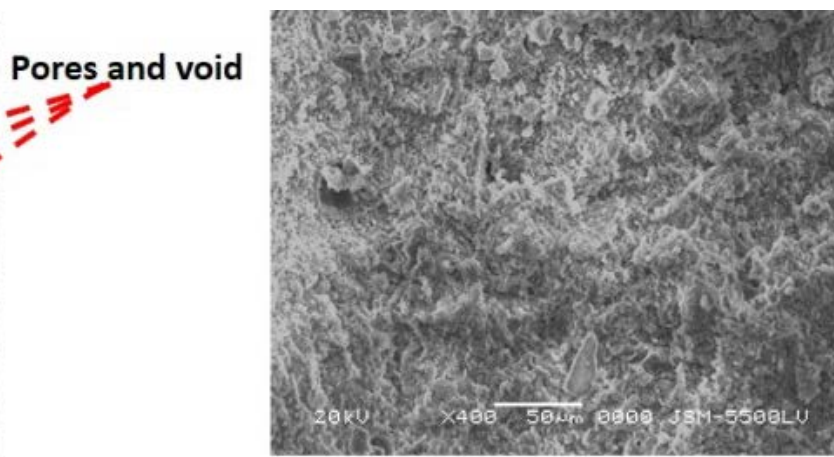

b) Limestone Coated B 72

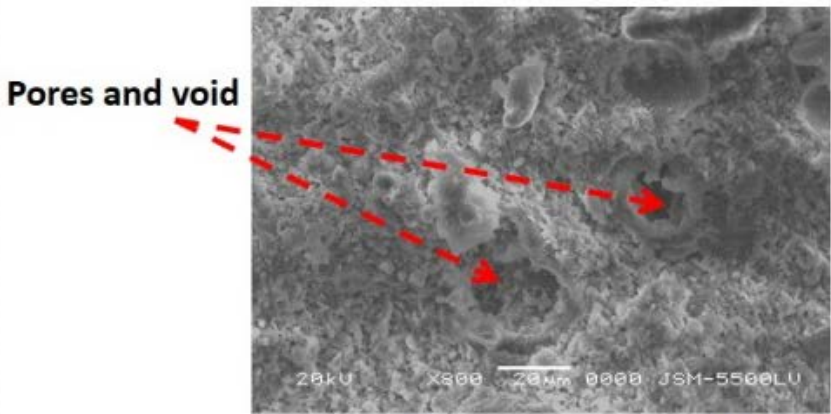

d) Limestone coated with ESI

Figure 3. SEM analysis of polymer coating homogeny distributed

Table 4. Enhancement with chemical coating before immersion process

\begin{tabular}{ccc}
\hline Coating types & \% strength increment & \% elongation \\
\hline Paraloid B44 & 214 & $60-$ \\
\hline Wacker OH100 & 200 & 70 \\
\hline Paraloid B72 & 50 & 64 \\
\hline Ethyl silicate & -2.5 & 26 \\
\hline
\end{tabular}

Table 5. Strength reduction with immersion action

\begin{tabular}{ccc}
\hline Coating types & \% strength increment & \% elongation \\
\hline Paraloid B44 & 42 & 24.8 \\
\hline Wacker OH100 & 95 & -66 \\
\hline Paraloid B72 & 12.8 & 64 \\
\hline Ethyl silicate & 71 & -60 \\
\hline
\end{tabular}

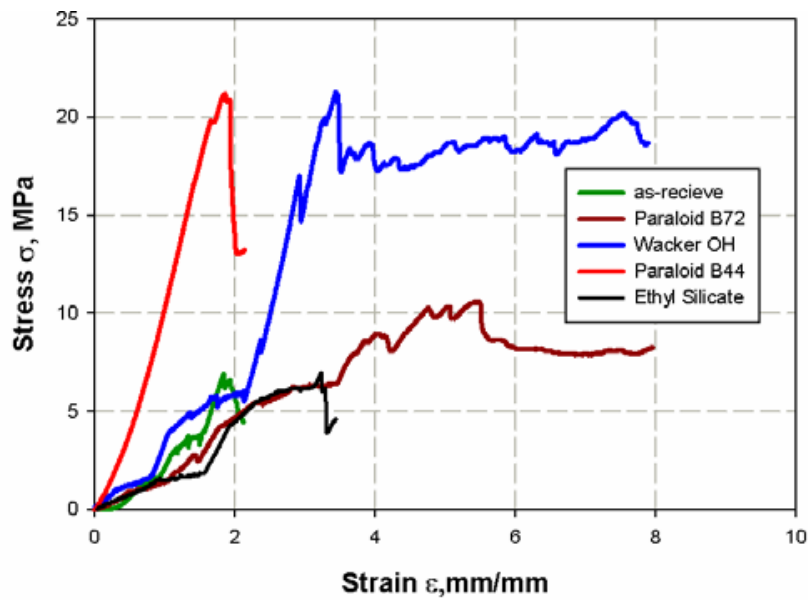

Figure 4. Compressive stress strain diagram for un-immersion coated limestone

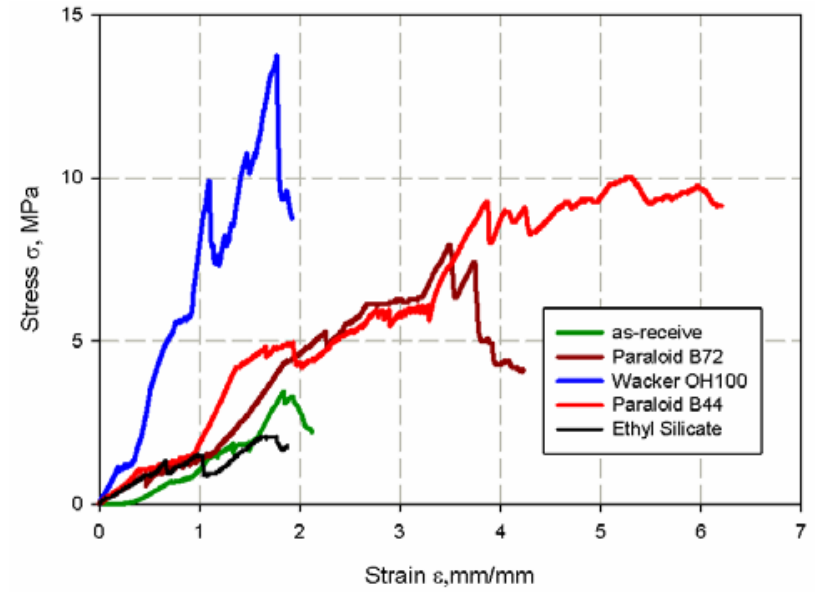

Figure 5. Compressive stress strain diagram for immersion coated limestone

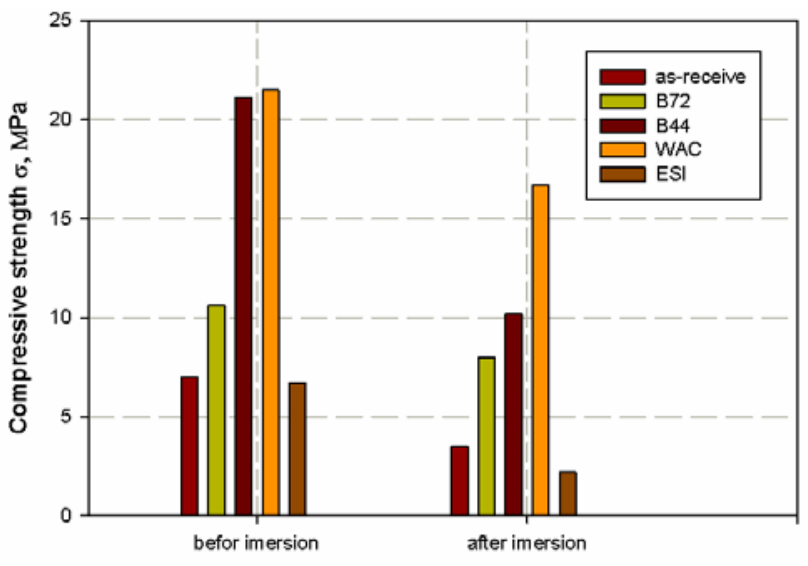

condition of limestone surface

Figure 6. Comparison coating efficiency 


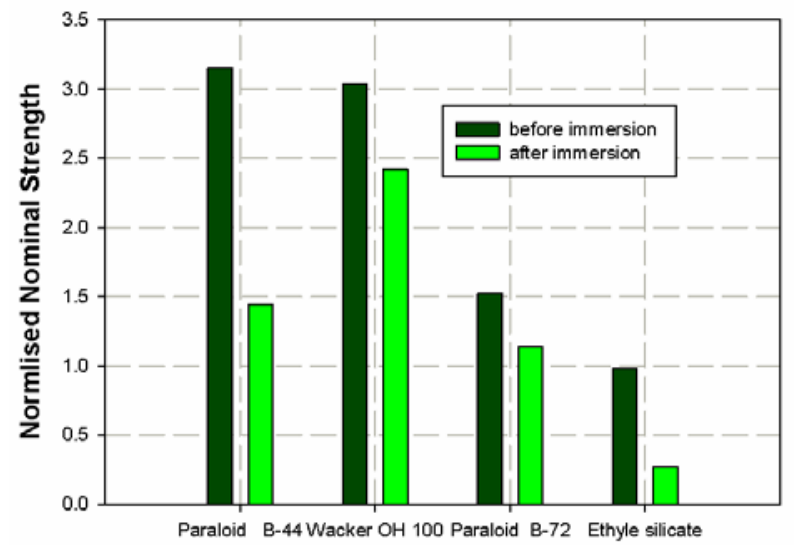

chemicals coating

Figure 7. Normalized nominal strength respect to different coating

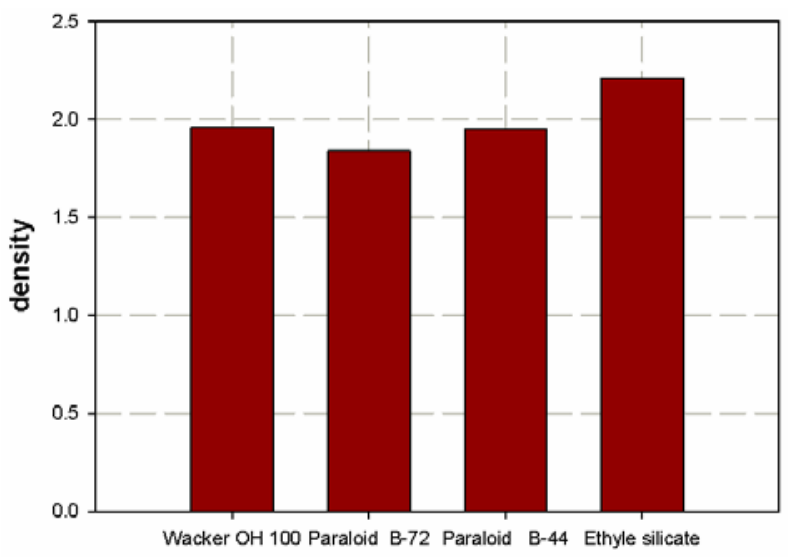

chemicals coating

Figure 8. Density variation with different chemical coating

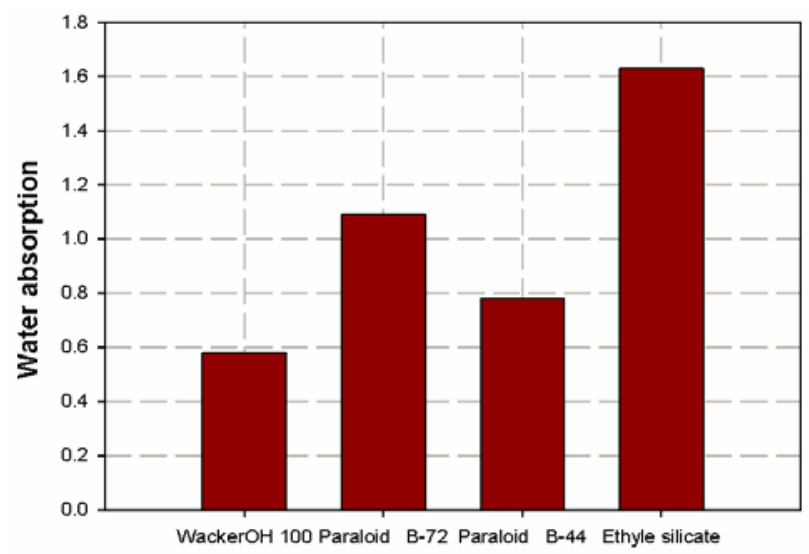

chemicals coating

Figure 9. Water absorption variation with chemical coating

It commonly originates from the deposition in wet and dry which sulfate products, attack carbonic rocks. The availability of sodium sulfuric $\left(\mathrm{Na}_{2} \mathrm{SO}_{4}\right)$ in the salinity water is the main reason for highly strength reduction of untreatable limestone (as received) when the specimen immersion in that water. While for coated ones (treatable one), the coating protects the limestone from a directly reaction. Therefore, the specimen resists the chemical action with different grade according to types and amount of coating and their diffusion and distribution over the limestone surface. It is clearly illustrated that Paraloid B44 and Wacker OH100 have more stability under salinity water. The strength reduction is also due to density stability of these coatings. Which is shown in Figure 8. The water absorption is enhanced with polymeric coatings of the limestone as shown in Figure 9. Figure 10 illustrates relative porosity with the coating polymer through limestone surfaced. It is clear that these polymers extended through the porosity of the limestone surface with a variety of grade. Ethyl silicate is clearly seen that it decreases with strength in both cases. This may be attributed to that Ethyl silicate is react with limestone itself forming a brittle tough material which cannot withstand the compressive load [28,29].

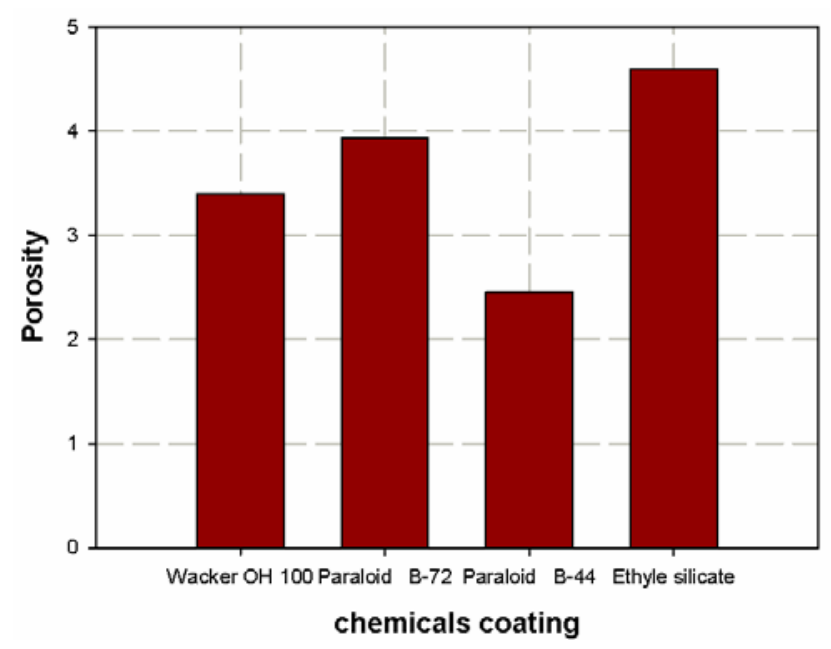

Figure 10. Porosity enhancement with chemical coating

\subsection{Weathering Failure mechanism of historic limestone}

There are four modes of failure due to weathering and natural environment. These modes can be surmised to;

- Cracks "Individual fissure, clearly visible to the naked eye, resulting from the separation of one part from another” as shown in Figure 11.

- Scratch: an indentation or material loss manually induced, it can be by accidents or intention. It appears like long thin width groove [30].

- Discoloration: Change of the stone color in one to three of the color parameters: hue value, and Chroma as shown in Figure 12.
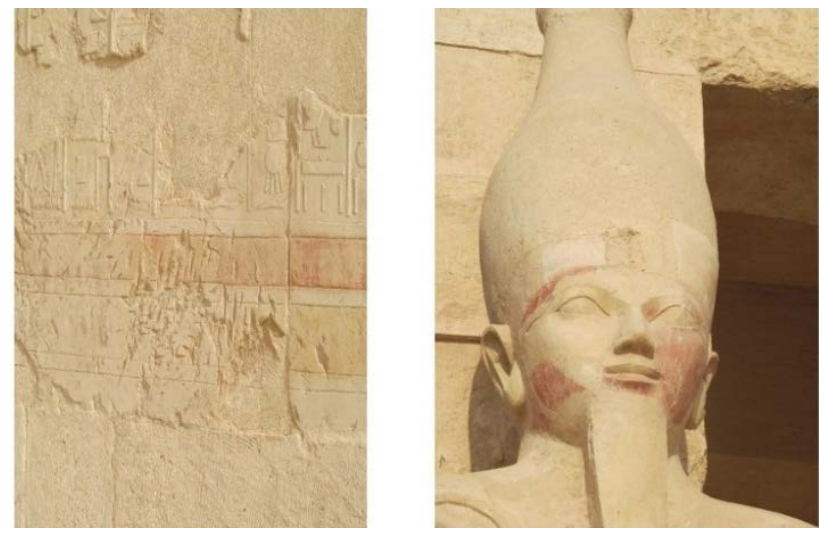

Figure 11. Deep crack in historic limestone 

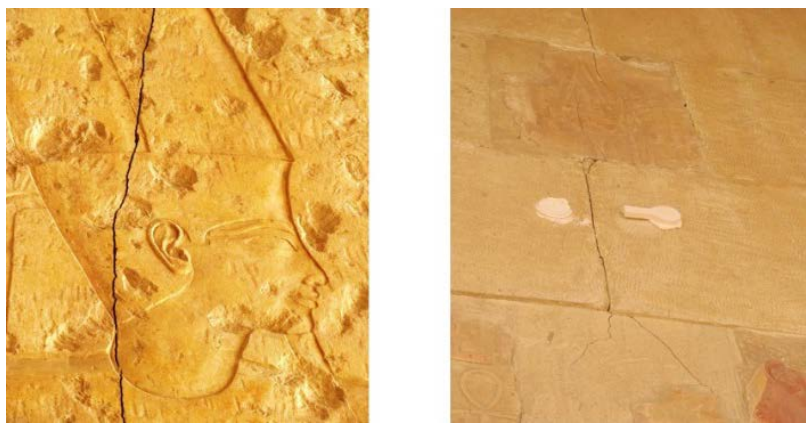

Figure 12. Discoloration in limestone

- - Hue corresponds to the most prominent characteristic of a color (blue, red, yellow, orange etc..).

- The Value corresponds to the darkness (low hues) or lightness (high hues) of a color.

- Chroma corresponds to the purity of a color. High Chroma colors appearance amusing and full. Low Chroma colors appearance cloudy and dirty. Sometimes Chroma is called saturation.

\section{Conclusion}

It is achieved that Thebes limestone can be protected well using polymer chemical coating. Compressive strength is enhanced nearly about $214 \%$ in case of un-immersion while $42 \%$ in case of immersion. Paraloid B44 and Wacker $\mathrm{OH} 100$ are the best common polymer coating which gives good bendability and good protection. The limestone surfaced protected with Ethyl Silicate is surmised to be dangerous and do not recommend although it spreads without pores and uniformly because it forms a brittle material with the historic deteriorates limestone. Water soaking is achieved well with all coating polymer. Porosity is enhanced clearly with the coating polymer chemical, especially with ethyl silicate.

\section{References}

[1] B. Holynska, J. Gilewicz - Wolter, B. Ostachowicz, M. Bielewski, C. Streli, and P. Wobrauschek, "Study of the deterioration of sandstone due to acid rain and humid $\mathrm{SO} 2$ gas," $X$-Ray Spectrometry, vol. 33, pp. 342-348, 2004.

[2] R. Kozłowski, A. Hejda, S. Cẹckiewicz, and J. Haber, "Influence of water contained in porous limestone on corrosion," Atmospheric Environment. Part A. General Topics, vol. 26, pp. 3241-3248, 1992.

[3] L. Leysen, E. Roekens, and R. Van Grieken, "Air-pollutioninduced chemical decay of a sandy-limestone cathedral in Belgium," Science of the total environment, vol. 78, pp. 263-287, 1989.

[4] J. L. Pérez Bernal and M. A. Bello, "Modeling sulfur dioxide deposition on calcium carbonate," Industrial \& engineering chemistry research, vol. 42, pp. 1028-1034, 2003.

[5] H. Sweevers and R. Van Grieken, "Analytical study of the deterioration of sandstone, marble and granite," Atmospheric Environment. Part B. Urban Atmosphere, vol. 26, pp. 159-163, 1992.

[6] G. Vleugels, B. Fobe, R. Dewolfs, and R. Van Grieken, "Surface composition alteration of bare and treated limestones after ambient exposure," Science of the total environment, vol. 151, pp. 59-69, 1994.

[7] G. Vleugels, E. Roekens, A. Van Put, F. Araujo, B. Fobe, R. Van Grieken, et al., "Analytical study of the weathering of the
Jeronimos Monastery in Lisbon," Science of the total environment, vol. 120, pp. 225-243, 1992.

[8] G. Vleugels and R. Van Grieken, "Suspended matter in run-off water from limestone exposure setups," Science of the total environment, vol. 170, pp. 125-132, 1995.

[9] P. Fowler, "World heritage cultural landscapes, 1992-2002: A review and prospect," Cultural landscapes: The challenges of conservation, p. 16, 2002.

[10] P. B. Lourenço, "Recommendations for restoration of ancient buildings and the survival of a masonry chimney," Construction and Building Materials, vol. 20, pp. 239-251, 2006.

[11] A. Cheshomi and E. A. Sheshde, "Determination of uniaxial compressive strength of microcrystalline limestone using single particles load test," Journal of Petroleum Science and Engineering, vol. 111, pp. 121-126, 2013.

[12] R. Nazir, E. Momeni, D. Jahedarmaghani, and M. Mohd Amin, "Prediction of unconfined compressive strength of limestone rock samples using L-type Schmidt hammer," Electr J Geotech Eng, vol. 18, pp. 1767-1775, 2013.

[13] M. Sadat-Shojai and A. Ershad - Langroudi, "Polymeric coatings for protection of historic monuments: Opportunities and challenges," Journal of Applied Polymer Science, vol. 112, pp. 2535-2551, 2009.

[14] M. Favaro, R. Mendichi, F. Ossola, U. Russo, S. Simon, P. Tomasin, et al., "Evaluation of polymers for conservation treatments of outdoor exposed stone monuments. Part I: photooxidative weathering," Polymer Degradation and Stability, vol. 91, pp. 3083-3096, 2006.

[15] A. Tuğrul, "The effect of weathering on pore geometry and compressive strength of selected rock types from Turkey," Engineering Geology, vol. 75, pp. 215-227, 11// 2004.

[16] Z. Karaca, N. Öztank, M. V. Gökçe, and H. Elçi, "Effects of surface-finishing forms and cement-filling on porous dimension limestone deterioration in cold regions," Cold Regions Science and Technology, vol. 68, pp. 124-129, 9// 2011.

[17] M. Y. Abdellah, A. Gelany, and M. M. A. Zeid, "Compressive and Failure Strength of Sand Stone with Different Strengthen Materials," American Journal of Materials Engineering and Technology, vol. 2, pp. 43-47, 2014.

[18] A. Tsakalof, P. Manoudis, I. Karapanagiotis, I. Chryssoulakis, and C. Panayiotou, "Assessment of synthetic polymeric coatings for the protection and preservation of stone monuments," Journal of Cultural Heritage, vol. 8, pp. 69-72, 1// 2007.

[19] M. Zielecka and E. Bujnowska, "Silicone-containing polymer matrices as protective coatings: Properties and applications," Progress in Organic Coatings, vol. 55, pp. 160-167, 2/1/ 2006.

[20] M. Brugnara, E. Degasperi, C. Della Volpe, D. Maniglio, A. Penati, S. Siboni, et al., "The application of the contact angle in monument protection: new materials and methods," Colloids and Surfaces A: Physicochemical and Engineering Aspects, vol. 241, pp. 299-312, 2004.

[21] D. Michoinová, "New materials for the protection of cultural heritage," ed: Praga, Czech Republic: Academy of Sciences, 2002.

[22] A. Nakajima, K. Abe, K. Hashimoto, and T. Watanabe, "Preparation of hard super-hydrophobic films with visible light transmission," Thin Solid Films, vol. 376, pp. 140-143, 2000.

[23] K. Satoh, H. Nakazumi, and M. Morita, "Preparation of superwater-repellent fluorinated inorganic-organic coating films on nylon 66 by the sol-gel method using microphase separation," Journal of sol-gel science and technology, vol. 27, pp. 327-332, 2003.

[24] M. M. A. ZEID, M. A. ATTIA, and M. Y. ABDELLAH, "STUDY THE USE OF RECYCLED AGGREGATES IN THE CASTING SHALLOW FOUNDATIONS," International Journal of Advances in Mechanical and Civil Engineering, vol. 2, pp. 4348, 2015.

[25] J. T. Han, Y. Zheng, J. H. Cho, X. Xu, and K. Cho, "Stable superhydrophobic organic-inorganic hybrid films by electrostatic self-assembly," The Journal of Physical Chemistry B, vol. 109, pp. 20773-20778, 2005.

[26] A. International, "Standard test method for evaluating properties of wood-base fiber and particle panel materials. ASTM D103706a," ed: ASTM International West Conshohocken, Pennsylvania, 2006.

[27] A. D2938-95, Standard Test Method for Unconfined Compressive Strength of Intact Rock Core Specimens West Conshohocken, PA: ASTM Internationa, 1995. 
[28] G. Parashar, D. Srivastava, and P. Kumar, "Ethyl silicate binders for high performance coatings," Progress in Organic Coatings, vol. 42, pp. 1-14, 2001.

[29] T. Shimizu, Y. Tachiyama, A. Kuroda, and M. Inagaki, "Effect of SO2 removal by limestone on NOx and N2O emissions from a bubbling fluidized-bed combustor," Fuel, vol. 71, pp. 841-844, 7// 1992.

[30] S. Shaw and J. Karmowska, "The multicultural heritage of European cities and its re-presentation through regeneration programmes," Multicultures and Cities, Copenhagen: Museum Tusculanum Press, University of Copenhagen, pp. 41-56, 2006. 